\title{
Klippel-Trenaunay syndrome: diagnosis in a neonate
}

\author{
Cátia Pereira, Rita Espírito Santo, Joana Saldanha
}

Department of Paediatrics, Neonatology Unit, Hospital Santa Maria, Centro Hospitalar Lisboa Norte, Lisboa, Portugal

\section{Correspondence to Dr Rita Espírito Santo, a.r. espiritosanto@gmail.com}

Accepted 27 June 2017

\section{CrossMark}

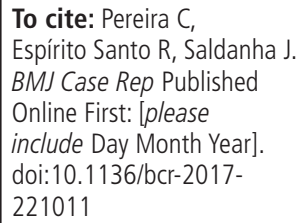

\section{DESCRIPTION}

A male newborn was evaluated due to a port-wine stain. Mother, 40 years old, father and brother were healthy. Gestation was uneventful. Amniocentesis revealed a normal male karyotype. A caesarean delivery was performed at 38 weeks. First physical examination showed a port-wine stain affecting the abdomen, back and left limb (figure 1) and hypertrophy of the affected limb. A biopsy was performed and histological findings revealed capillary malformations. Therefore, a Klippel-Trenaunay syndrome was diagnosed. Abdominal and lower limb doppler ultrasound and brain MRI excluded other vascular abnormalities. He was followed by a multidisciplinary team. At 9 months, there was a slight difference in the length of legs and the circumference of thighs (figure 2).

Klippel-Trenaunay syndrome is a rare disease, characterised by capillary and venous malformations and soft tissue or bone hypertrophy with overgrowth of the affected extremity. ${ }^{1}$ Its aetiology remains unknown. ${ }^{2}$ Klippel-Trenaunay syndrome affects both genders equally. ${ }^{1}$ The cutaneous capillary malformation presenting as a port-wine stain and limb hypertrophy are usually noted at birth. ${ }^{2}$ Some cases presenting with atrophy and reduced growth of the affected limb have been described. Venous malformations may be present at birth or appear during infancy. ${ }^{1}$ The lower extremity is the

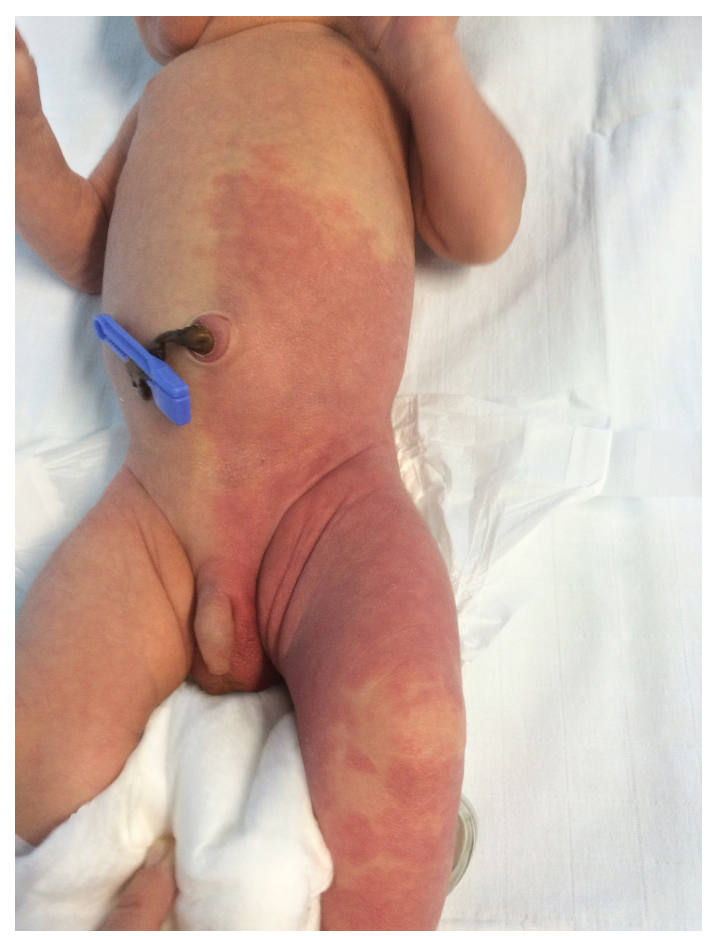

Figure 1 A port-stain affecting the abdomen and left limb at first physical examination of the neonate.

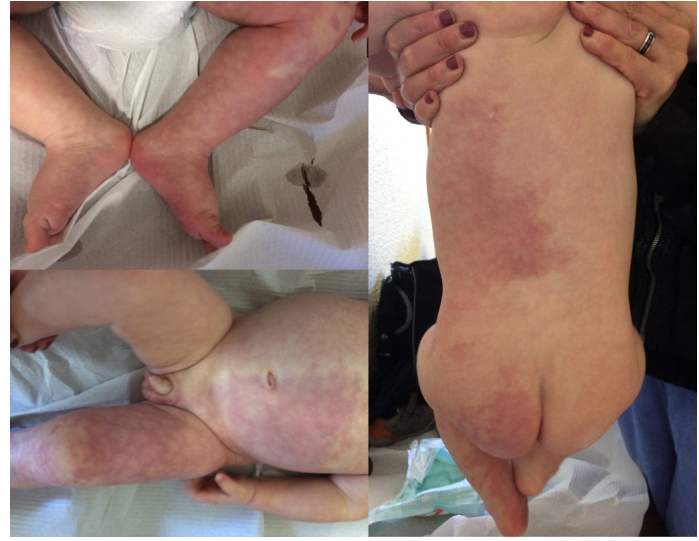

Figure 2 Appearance of the abdomen, trunk and limbs at 9 months of age.

most commonly affected. However, it can involve upper limbs and extends to the trunk. ${ }^{2}$ Doppler ultrasound allows to identify abnormalities of the venous system and MRI helps to characterise vascular malformations. ${ }^{12}$ Complications may include limb-length discrepancy leading to impaired gait and pain, thromboembolism, bleeding, venous insufficiency and soft-tissue infection. ${ }^{13}$ Treatment is mainly supportive and includes management of complications. ${ }^{1}$

\section{Learning points}

- Klippel-Trenaunay syndrome is a rare disease, presenting with a port-wine stain and limbs asymmetry.

- Physicians, namely neonatologists and paediatricians, should be aware of KlippelTrenaunay syndrome in order to be able to make an accurate diagnosis and treat complications.

Contributors CP, RES and JS conducted the analysis of the described case. CP drafted the manuscript. RES and JS critically reviewed the manuscript. All the authors read and approved the final version.

Competing interests None declared.

Patient consent Obtained from guardian.

Provenance and peer review Not commissioned; externally peer reviewed.

(C) BMJ Publishing Group Ltd (unless otherwise stated in the text of the article) 2017. All rights reserved. No commercial use is permitted unless otherwise expressly granted.

\section{REFERENCES}

1 Frieden I, Chu D. Klippel-Trenaunay syndrome: Clinical manifestations, diagnosis, andmanagement. In: Post TW, ed. UpToDate. Waltham, MA: Wolters Kluwer, 2017. http://www.uptodate.com (accessed 18 Jan 2017). 


\section{Images in...}

2 Hannawi S, Salmi I, Syndrome KT. Klippel Trenaunay syndrome, inverse Klippel Trenaunay syndrome: hypertrophy of lower limbs and atrophy of the upper limbs and facial muscles: case report and literature review. J Clin Exp Dermatol Res 2013;04:1.
3 Sharma D, Lamba S, Pandita A, et al. Klippel-trénaunay syndrome - a very rare and interesting syndrome. Clin Med Insights Circ Respir Pulm Med 2015;9:1-4.

Copyright 2017 BMJ Publishing Group. All rights reserved. For permission to reuse any of this content visit http://group.bmj.com/group/rights-licensing/permissions.

BMJ Case Report Fellows may re-use this article for personal use and teaching without any further permission.

Become a Fellow of BMJ Case Reports today and you can:

- Submit as many cases as you like

- Enjoy fast sympathetic peer review and rapid publication of accepted articles

- Access all the published articles

- Re-use any of the published material for personal use and teaching without further permission

For information on Institutional Fellowships contact consortiasales@bmjgroup.com

Visit casereports.bmj.com for more articles like this and to become a Fellow 